\title{
The Silent Gene for Serum Pseudocholinesterase
}

\author{
A. SZEINBERG, SERENA PIPANO, E. OSTFELD, and L. EVIATAR
}

From the Departments of Chemical Pathology and Anaesthesia, Tel Aviv University Medical School, Government Hospital Tel Hashomer, Tel Hashomer, Israel

The investigations of human serum pseudocholinestrase (acylcholine acylhydrolase) (International Union of Biochemistry, . 1961 : 3.1.1.8) suggest the existence of four allelic genes controlling the formation of different enzyme types: gene $E_{1}{ }^{u}$ for usual esterase, $\mathrm{E}_{1}{ }^{\mathrm{a}}$ for atypical (dibucaine resistant) esterase, $E_{1}{ }^{f}$ for a fluoride-resistant type, and $\mathrm{E}_{1}{ }^{s}$ for a 'silent' gene. The four genes result in the existence of ro different genotypes (Harris, 1964).

Until now 7 cases (in 6 families) of complete pseudocholinesterase deficiency, compatible with the homozygous genotype $\mathrm{E}_{1}{ }^{s} \mathrm{E}_{1}{ }^{s}$, have been described (Liddell, Lehmann, and Silk, 1962; Doenicke, Gürtner, Kreutzberg, Remes, Spiess, and Steinbereithner, 1963; Hodgkin, Giblett, Levine, Bauer, and Motulsky, 1965; Goedde, Fuss, Ritter, and Baitsch, 1965a; Dietz, Lubrano, and Rubinstein, 1965). During a survey on the frequency of atypical pseudocholinesterase in various population groups in Israel, a new case of complete absence of the enzyme was detected by us. Family examinations demonstrated a similar absence of enzyme activity in the serum of two children of the propositus (Fig.). The present report describes the detailed findings in the affected family.

\section{Material and Methods}

The survey has been conducted on a random sample of blood bank donors and hospital patients not suffering from liver, kidney, or neoplastic diseases. All the sera were examined by the screening paper-spot test of Harris and Robson (1963), modified as follows: filter paper Whatman No. 3IET was used instead of No. 17, the control tubes contained $0.05 \mathrm{ml}$. serum diluted in $2 \mathrm{ml}$. phosphate buffer instead of $4 \mathrm{ml}$. as originally described. All the samples, which in the screening test suggested the presence of atypical enzyme or showed low enzymatic activity, were examined for definitive classification by spectrophotometric procedures for pseudocholinesterase activity and the dibucaine number

Received February 24, 1966.
(Kalow and Genest, 1957), fluoride number (Harris and Whittaker, I96I), and inhibition by $\mathrm{RO}_{2}-0683$ (Liddell Lehmann, and Davies, 1963).

All the determinations were carried out in BeckmanDU spectrophotometer at $240 \mathrm{~m} \mu$ at $26^{\circ} \mathrm{C}$. The enzymeo activity was expressed in arbitrary units defined byo Kalow and Lindsay (1955) as micromoles of acetylcholine hydrolysed by $1.0 \mathrm{ml}$. serum in one hour atcs $37^{\circ} \mathrm{C}$. The normal range of activity obtained upon examination of 108 adult healthy blood donors was $130-378$ units, mean \pm S.D. $=247 \cdot 0 \pm 50 \cdot 7$ units.

\section{Results}

During the survey 2347 subjects were examined; 9I cases of the intermediate phenotype $\left(E_{1}{ }^{a} E_{1}{ }^{a}\right)$ and 4 of the atypical phenotype(most probably $\mathrm{E}_{1}{ }^{a} \mathrm{E}_{1}{ }^{\mathrm{a}} \mathrm{O}$ genotype) were found. Subdivision of the material s according to the ethnic origin of the subjectso suggested the existence of significant differences in the frequency of the $E_{1}{ }^{a}$ gene between some Jewish $\triangle$ groups. A detailed presentation of these results has $\overrightarrow{\overrightarrow{\widehat{O}}}$ been reported (Szeinberg, Pipano, and Ostfeld, 3 1966).

Among the subjects examined during the survey, one healthy blood bank donor (45 year-old Jewish male, born in Morocco) did not demonstrate anyo serum pseudocholinesterase activity in the screening test. No activity was also demonstrated by the spectrophotometric assay using $1 / 200,1 / 100$, or $1 / 400$ ก dilutions of the serum. A second sample obtained $₹$ two weeks later gave similar results. Of the 9을 children of the propositus, 6 were examined, and $>$ 2 sons (III.6 and III.7) did not demonstrate any으. pseudocholinesterase activity; 2 other sons, $2 \hat{N}$ daughters (III.2, III.3, III.4, III.5), and the wife. of the propositus (II.I) had enzyme activities of $169, \mathrm{~N}$ $163,175,130$, and 140 units with normal inhibition $N_{\omega}^{N}$ characteristics (Table). There was no consanguinityo between the propositus and his wife.

The absence of pseudocholinesterase activity in the 2 sons suggested that, either their mother was $\stackrel{?}{?}$ also a carrier of the silent gene, or that we had 0 encountered a family with an unusual mutation, namely a dominant inheritance of the silent gene. 


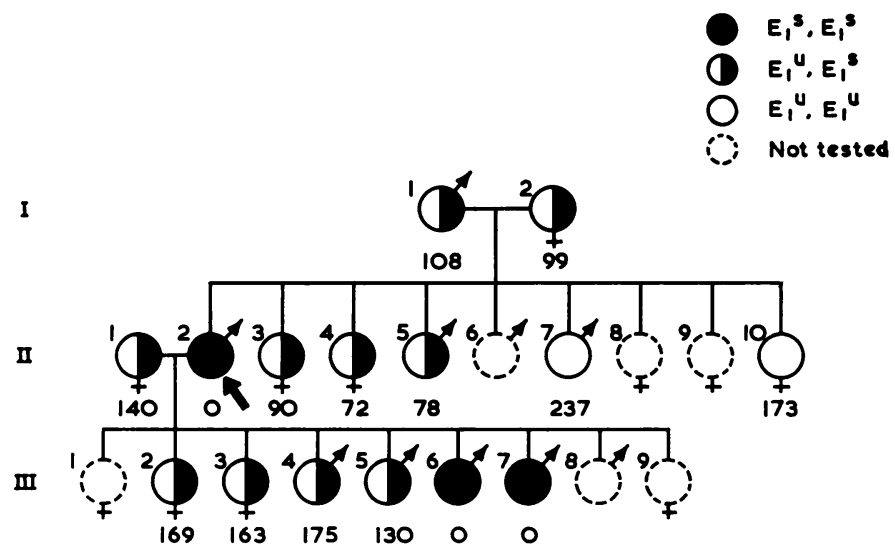

FIG. I. The probable genetic make-up of the investigated family. The numbers represent the enzyme activity.

In view of those two alternative possibilities, additional members of the family were examined. The father of the propositus (I.I) had I08 units and the mother (I.2) 99 units enzyme activity with normal inhibition characteristics. These results negated the probability of a dominant transmission of the silent gene and suggested that both parents were of the heterozygous $\mathrm{E}_{1}{ }^{\mathrm{u}} \mathrm{E}_{1}{ }^{\mathrm{s}}$ genotype, as the activity of their sera was below the normal limit. Among 5 sibs of the propositus, 3 (II.3, 4, 5) had low enzyme activity (90, 72, 78 units) compatible with genotype $\mathrm{E}_{1}{ }^{\mathrm{u}} \mathrm{E}_{1}{ }^{\mathrm{s}}$, and 2 (II.7, 10) normal activity (237 and $\mathrm{I} 73$ units) compatible with genotype $E_{1}{ }^{u} E_{1}{ }^{u}$.

According to this analysis the most probable explanation of the absence of enzyme activity in the two members of the third generation was an inheritance of recessive silent genes both from the propositus and his wife. The fact that the wife had enzyme activity of 140 units, i.e. above the lower normal limit, did not preclude the possibility of a heterozygous $E_{1}{ }^{u} E_{1}{ }^{s}$ genotype. It has been conclusively demonstrated in other families reported so far that persons of this genotype may have enzyme activities within the normal range (Liddell et al., 1962; Simpson and Kalow, 1964; Hodgkin et al., 1965; Szeinberg, Pipano, and Ostfeld, 1965; Dietz et al., 1965). The most probable genetic make-up of the investigated family is presented in the figure.

Lehmann and Liddell (1964) demonstrated a slight inhibition of normal pseudocholinesterase

TABLE

RESULTS OF THE FAMILY INVESTIGATION

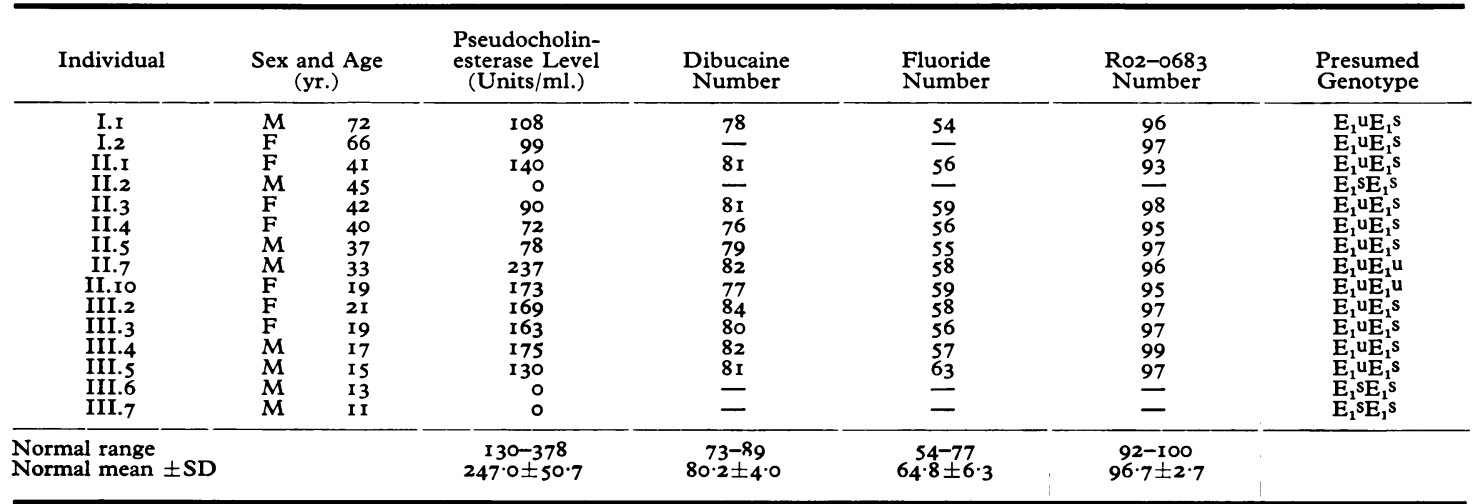


activity by serum from the patient with complete pseudocholinesterase deficiency. No such inhibition could be demonstrated in the cases reported by Hodgkin et al. (1965). Sera of our 3 subjects with complete absence of activity were investigated for inhibitory activity in the following experiment: equal volumes of normal serum and anenzymic serum were mixed. The mixture was tested immediately for pseudocholinesterase activity; in addition one part of the mixture was incubated at $37^{\circ} \mathrm{C}$. for 30 minutes and I hour, another aliquot was diluted I : IOO with the phosphate buffer used for the pseudocholinesterase activity estimation and also incubated for 30 minutes and I hour. None of the mixtures demonstrated any evidence for the presence of inhibitor in the anenzymic sera.

\section{Discussion}

Starch gel electrophoresis of serum of the 2 cases of Hodgkin et al. (1965) showed absence of the 4 isozyme bands associated with normal pseudocholinesterase activity. Immunological studies indicated that these subjects did not produce any antigenically similar protein detectable by the methods used. On the other hand, Goedde, Gehring, and Hofmann (1965b) who studied 2 cases, which did not show any pseudocholinesterase activity in the spectrophotometric assays, demonstrated a slight esterase activity ( $2-3 \%$ of normal) by a micromanometric assay. The activity was located at the $\mathrm{C}_{4}$ isozyme band after starch gel electrophoresis of serum. In addition, immunological investigations demonstrated the presence of a protein antigenically similar to the usual pseudocholinesterase protein. Further investigations are required in order to establish whether the divergent results obtained by the two groups of investigators were due to differences in techniques, or to the existence of different mutants of the so-called 'silent gene'.

All the presently available pedigree data suggest that the silent gene is an allele of the normal esterase and its two allelic mutants $\left(\mathrm{E}_{1}{ }^{\mathrm{a}}\right.$ and $\left.\mathrm{E}_{1}{ }^{\mathrm{f}}\right)$. However, an alternative hypothesis has been also discussed by Simpson and Kalow (1964), namely that the gene determining absence of pseudocholinesterase is an independent, non-allelic gene which suppresses the action of $E_{1}{ }^{u}$ or $E_{1}{ }^{a}$ genes. The presence of a gene suppressing the action of $E_{1}{ }^{u}$ was not considered to be likely, as it would predict too high frequency for individuals without pseudocholinesterase activity. The hypothesis of a suppressor of $\mathrm{E}_{1}{ }^{\mathrm{a}}$ gene was excluded on the grounds that no segregation of $E_{1}{ }^{a}$ gene was observed among relatives of persons with the hypothetical genotype $\mathrm{E}_{1}{ }^{\mathrm{u}} \mathrm{E}_{1}{ }^{\mathrm{a}} \mathrm{Ss}$ (s represents the suppressor gene and $S$ its non-suppressor allele This conclusion (with a chance probability $p=0.02$ ) was based on results seen in 14 offspring in a critical type of mating. Hodgkin et al. (1960) suggested that more offspring from the critic 11 matings were required to disprove this remo hypothesis.

The material available for such an analysis has now been enlarged. The critical matings analysed by the previous investigators were between normats $\left(\mathrm{E}_{1}{ }^{ } \mathrm{E}_{1}{ }^{\mathrm{u}} \mathrm{SS}\right)$ and silent gene heterozygotes $\left(\mathrm{E}_{1}{ }^{\mathrm{u}} \mathrm{E}_{1}{ }^{\mathrm{a}} \mathrm{S} S{ }^{\circ}\right.$. 3 children of such a mating were present in a fami described previously by us (subjects III.3, 4, 5, 角 Szeinberg et al. (1965) and 3 children in the family described by Dietz et al. (1965) (subjects III.22, 23 , 24 in family G). All were phenotypically norma. Thus the number of phenotype $U$ offspring in the type of mating is now 20 , and the probability of this being a chance occurrence is $(3 / 4)^{20}=0.003$.

In the family described here, additional typ of mating provide material for testing the suppressor gene theory. Both parents of th propositus are obligatory heterozygotes $\left(\mathrm{E}_{1}{ }^{\mathrm{u}} \mathrm{E}_{1}{ }^{\mathrm{a}} \mathrm{S} \underline{\mathrm{s}}\right)$ and their mating should result in 10/16 phenotypos $\mathrm{U}$, and 2/16 phenotype I (intermediate dibucaire resistant), 3/16 phenotype A (atypical dibucaine resistant), and I/16 homozygous silent gene childre (on the assumption (Simpson and Kalow, 1964) the one suppressor gene does not completely suppre the action of two $\mathrm{E}_{1}{ }^{\mathrm{a}}$ genes). Five sibs. of the pres positus were tested and all were phenotypically In the family of Hodgkin et al. (1965) two sibs \&f the propositi, and in the family ' $C$ ' of Dietz et at. (1965) one sister of the propositus also show normal dibucaine resistance. The probability of not finding cases with increased dibucaine resistan $\vec{g}$ among these 8 offspring is $(1 \mathrm{I} / \mathrm{I} 6)^{8}=0.049$.

The mating between the propositus of our family. (homozygote silent $\mathrm{E}_{1}{ }^{a} \mathrm{E}_{1}{ }^{\mathrm{a}} \mathrm{ss}$ ) and his wife (hetero zygous silent $\mathrm{E}_{1}{ }^{ } \mathrm{E}_{1}{ }^{\mathrm{a}} \mathrm{Ss}$ ) should produce $\mathrm{I} / 4$ dibucaine resistant $\mathrm{E}_{1}{ }^{a} \mathrm{E}_{1}{ }^{2} \mathrm{Ss}$ (phenotype $\mathrm{A}$ ) offspring. Among the 6 examined children of this couple none with the atypical enzyme was found, the probability of chance being $(3 / 4)^{6}=0.178$.

The combined data from all the critical matings exclude the hypothesis that the silent gene is independent of $E_{1}$ locus and suppresses the action of $E_{1}^{a}$ gene with the probability of $(3 / 4)^{20} \times(11 / 1)$ $\times(3 / 4)^{6}$, i.e. about 0.00003 .

Hodgkin et al. (1965) suggested that the heterozygotes $\mathrm{E}_{1}{ }^{\mathrm{u}} \mathrm{E}_{1}{ }^{\mathrm{s}}$ produced on the average about two-thirds of the enzyme activity of normal hom zygotes. This conclusion was based on results seern in 5 obligatory heterozygotes studied by them, studied by Simpson and Kalow (1964), and a personast 
communication of Harris (Hodgkin et al., 1965). The individual variations were, however, very large (range of $28-113 \%$ of mean normal activity in the material of Simpson and Kalow (1964), and 3I-83\% in that of Hodgkin et al. (1965)), and obviously additional information would be valuable in this respect. There were Io obligatory heterozygotes $\mathrm{E}_{1}{ }^{\mathrm{u}} \mathrm{E}_{1}{ }^{\mathrm{s}}$ in the families described by Dietz et al. (1965): the mean enzyme activity in the males was $75 \%$ (range $68-83 \%)$ and among the females $78 \%(63-99 \%)$ of mean normal activity. The two obligatory heterozygotes in the family of Case Io described by Goedde et al. (1965a) had $59 \%$ and $39 \%$ of mean normal activity. In the families described by us there were Io obligatory heterozygotes (II.I, 4, 7, in Szeinberg et al. (I965)); and I.I, 2; II.I; III.2, 3, 4,5 in the present communication). The mean activity in these ro subjects was $53 \%$ of mean normal and the range was $40-71 \%$. In view of these results it seems that the collection of more data is indicated in order to decide whether persons with only one $\mathrm{E}_{1}{ }^{\mathrm{u}}$ gene produce significantly more than one-half of normal enzyme activity. It should be remembered that this type of investigation is further complicated by the influence of age, sex, and environmental factors on the serum pseudocholinesterase activity, as demonstrated by Simpson and Kalow (1963).

\section{Summary}

A Jewish family from Morocco with a complete absence of serum pseudocholinesterase activity in father and two sons was discovered during a population screening in Israel. The family data were compatible with the hypothesis that these cases were homozygous for the 'silent gene', allelic to the 'usual' pseudocholinesterase gene.

Genetic considerations from this and previously reported families exclude an alternative hypothesis, that the 'silent' gene is independent of the $E_{1}$ locus and suppresses the action of the $\mathrm{E}_{1}^{\mathrm{a}}$ gene, with a probability of about 0.00003 .

Serum with complete absence of pseudocholinesterase activity failed to inhibit normal pseudocholinesterase activity.

Heterozygotes for the 'usual' and 'silent' genes in the present family and another one previously described by the authors had a mean of $53 \%$ of normal enzyme activity ( $r$ inge $40-71 \%$ ).
We thank Dr. L. Dressler, the Director of the Blood Bank at Tel Hashomer Hospital, and his staff for their help in obtaining samples from blood donors. We would also like to thank Dr. Miriam Gold, from the Workers Sick Fund Clinic, Zur Shalom, for her help in securing contact with several members of the investigated family.

We would also like to thank the Hoffmann-La Roche Co. (Basle) for a gift of $\mathrm{RO}_{2}-0683$, and the Ciba Ltd. (Basle) for dibucaine hydrochloride (Nupercaine- $\mathrm{HCl}$ ).

\section{REFERENCES}

Dietz, A. A., Lubrano, T., and Rubinstein, H. M. (1965). Four families segregating for the silent gene for serum cholinesterase. Acta genet. (Basel), 15, 208.

Doenicke, A., Gürtner, T., Kreutzberg, G., Remes, I., Spiess: W., and Steinbereithner, K. (1963). Serum cholinesterase anenzymia: report of a case confirmed by enzyme-hystochemical examination of liver-biopsy specimen. Acta anaesth. scand., 7, 59.

Goedde, H. W., Fuss, W., Ritter, H., and Baitsch, H. (1965a). Úber die Verwendung des Pseudocholinesterase-Polymorphismus im Paternitätsgutachten. Humangenetik, I, 31 I.

- Gehring, D., and Hofmann, R. A. (1965b). On the problem of a "silent gene" in pseudocholinesterase polymorphism. Biochim. biophys. Acta (Amst.), ro7, 391 .

Harris, H. (1964). The genetics of serum cholinesterase 'deficiency' in relation to suxamethonium apnoea. Proc. roy. Soc. Med, 57, 503

, and Robson, E. B. (1963). Screening tests for the "atypical" and "intermediate" serum-cholinesterase types. Lancet, 2, 218.

_- and Whittaker, M. (I96I). Differential inhibition of human serum cholinesterase with fluoride: recognition of two new phenotypes. Nature (Lond.), 191, 496.

Hodgkin, W. E., Giblett, E. R., Levine, H., Bauer, W., and Motulsky, A. G. (I965). Complete pseudocholinesterase deficiency: genetic and immunologic characterization. $\mathcal{f}$. clin. Invest., 44, 486 .

International Union of Biochemistry (196I). Report of the Commission on Enzymes. Pergamon Press, Oxford.

Kalow, W., and Genest, K. (1957). A method for the detection of atypical forms of human serum cholinesterase. Determination of dibucaine numbers. Canad. F. Biochem., 35, 339.

_- and Lindsay, H. A. (I955). A comparison of optical and manometric methods for the assay of human serum cholinester? ibid., 33, 568 .

Lehmann, H., and Liddell, J. (1964). Genetical variants o' isuman serum pseudocholinesterase. Progr. med. Genet., 3, 75.

Liddell, J., Lehmann, H., and Davies, D. (1963). Harris anc' Whittaker's pseudocholinesterase variant with increased resisiance to fluoride. Acta genet. (Basel), 13, 95.

- - , and Silk, E. (1962). A "silent" pseudochol.nesterase gene. Nature (Lond.), 193, 561.

Simpson, N. E., and Kalow, W. (1963). Serum cholinestera-e levels in families and twins. Amer. F. hum. Genet., 15, 280.

, and - (1964). The "silent" gene for serum cholinesterase. ibid., 16, 180 .

Szeinberg, A., Pipano, S., and Ostfeld, E. (1965). A silent pseudocholinesterase gene. Marked suxamethonium sensitivity in a person heterozygous for the atypical and silent pseudocholinesterase genes. Acta genet. (Basel), 15, 201.

- - and - (1966). Frequency of atypical pseudocholinesterase in different population groups in Israel. Acta anaesth. scand. In the press. 